\title{
The construction of collective competencies in the dynamics of budgetary routines
}

\author{
SAMANTHA LUIZA de SOUZA BROMAN ${ }^{1}$ \\ ROBERTO LIMA RUAS ${ }^{2}$ \\ SANDRA REgINA DA ROCHA-PINTO ${ }^{1}$
}

\author{
1 PontifíCIA Universidade Católica do RIO de JaneIro (IAG/PUC- RIO), RIO DE JANEIRO - RJ, BRAZIL
}

2 UNIVERSIDAde NoVE DE JULHo (PPGA/UNINOVE), SÃo PAULO - SP, BRAZIL

\begin{abstract}
The growing diffusion of collective work configurations in the current organizational environment has remained largely overlooked in the scientific body of work on the theme (BOREHAM, 2011). Paradoxically, however, certain currents in the debate about organizations highlight the role of collective work, as is the case with the literature on organizational routines (NELSON and WINTER, 2005; PENTLAND and FELDMAN, 2005). The question that motivates this investigation explores the relationship between those two themes: can the dynamics of corporate budgeting constitute an adequate space for the formation and development of collective competences? The objective of this question is an inquiry into the design of corporate budgets, from an organizational-routine approach, to identify evidence of teamwork and the formation of collective competences and attributes. The responses transit through a qualitative and phenomenographic investigation that pointed to four descriptive categories of collective work: commitment to deliver, reconfiguration of routines, shared availability, and building relationship networks. The contributions of the research include the potential of the organizational routines theory as a reference for the analysis of corporate processes, the identification of processes capable of contributing to the management of workgroups, and the use of the phenomenographic method as an alternative to frame somewhat intangible organizational phenomena.
\end{abstract}

Keywords: Organizational routines. Collective competencies. Dynamic routines. Phenomenography.

\section{A construção de competências coletivas na dinâmica das rotinas orçamentárias}

\section{Resumo}

A crescente difusão de configurações coletivas de trabalho no atual ambiente organizacional não tem apresentado contrapartida na produção científica sobre o tema (BOREHAM, 2011). Paradoxalmente, porém, alguns campos do debate sobre organizações destacam o papel dos coletivos de trabalho, como é o caso da literatura sobre Rotinas Organizacionais - RO - (NELSON e WINTER, 2005; PENTLAND e FELDMAN, 2005). A questão que mobiliza esta investigação explora a relação entre esses dois temas: a dinâmica das rotinas orçamentárias corporativas pode constituir um espaço adequado para a formação e o desenvolvimento de competências coletivas? O objetivo é examinar a elaboração de orçamentos corporativos, com base na abordagem de rotina organizacional, a fim de identificar evidências de coletivos de trabalho e da formação de atributos e competências coletivas. Essas respostas transitam por uma investigação qualitativa e fenomenográfica que apontou quatro categorias descritivas da configuração coletiva do trabalho: Comprometimento com a Entrega, Reconfiguração das Rotinas, Disponibilização Compartilhada e Construção de Redes de Relacionamento. De entre as contribuições da pesquisa, destaque para: o potencial da teoria das RO como referência a análise de processos corporativos; identificação de processos capazes de contribuir na gestão de coletivos de trabalho; e o emprego do método fenomenográfico como alternativa para apropriar fenômenos organizacionais de natureza pouco tangíveis.

Palavras-chave: Rotinas Organizacionais. Competências Coletivas. Dinâmica das Rotinas. Fenomenografia.

\section{La construcción de competencias colectivas en la dinámica de las rutinas presupuestarias}

\section{Resumen}

La creciente difusión de configuraciones colectivas de trabajo en el actual ambiente organizativo no ha presentado contrapartida en la producción científica acerca del tema (BOREHAN, 2011). Paradójicamente, sin embargo, algunos ámbitos del debate sobre las organizaciones subrayan el papel de los colectivos de trabajo, como es el caso de la literatura sobre Rutinas Organizativas (NELSON y WINTER, 2005; PENTLAND y FELDMAN, 2005). La cuestión que motiva esta investigación explora la relación entre esos dos temas: ¿la dinámica de rutinas presupuestarias corporativas puede constituirse en un espacio adecuado a la formación y el desarrollo de competencias colectivas? Su objetivo es analizar la elaboración de presupuestos corporativos, basado en el enfoque de la rutina organizativa, con el fin de identificar evidencias de colectivos de trabajo y de la formación de atributos y competencias colectivas. Esas respuestas pasan por una investigación cualitativa y fenomenográfica que ha señalado cuatro categorías descriptivas de la configuración colectiva del trabajo: Compromiso con la Entrega, Reconfiguración de Rutinas, Ofrecimiento compartido y Construcción de Redes de Relaciones. Entre los aportes de la investigación, es notable el potencial de la teoría de las RO, como referencia al análisis de procesos corporativos, identificación de procesos capaces de contribuir a la gestión de colectivos de trabajo y el empleo del método fenomenográfico como alternativa para la apropiación de fenómenos organizativos de naturaleza poco tangibles.

Palabras clave: Rutinas organizativas. Competencias colectivas. Dinámica de rutinas. Fenomenografía. 


\section{INTRODUCTION}

The growth in collective working arrangements within organizations, resulting from appropriation of digital communication, horizontal information networks, and the need to share knowledge and expertise through internal and external relationships (BOREHAM, 2011), has been largely neglected in academic writing on the subject. Indeed, relevant questions about work collectives, such as their attributes and competencies, for example, remain unanswered, constituting a research gap that is rarely acknowledged in the debate on organizational management (MICHAUX, 2011; RETOUR and KROHMER, 2011; LOUFRANIFEDIDA and MISSONIER, 2015; MACKE and CRESPI, 2016). Paradoxically, some areas of the literature on organizations highlight the issue of collective working configurations and emphasize the role of work collectives. One such field is the area dedicated to the study of Organizational Routines.

Within the concept of organizational routines, which is one of the foundations of the Evolutionary Theory (NELSON and WINTER, 2005), attention has focused on organizational behaviors that are repeated but which, under influence from the environment external to the organization, tend to incorporate significant change into their configurations (NELSON and WINTER, 2005). From this perspective, the collective dimension of organizational routines is a fundamental element in consolidation of routines, to the extent that it overlays and directs individual initiatives (NELSON and WINTER, 2005); and both Michaux (2011), and Feldman and Pentland (2003) also hold that organizational routines have their origins in collective experiences and practices and consider that organizational routines are structured on the basis of collective not individual routines. Thus, the dynamics of organizational routines may provide an opportunity for increasing knowledge and expanding the debate about work collectives, especially their attributes and competencies. In view of this, we examine the production of corporate budgeting routines, which, for the purposes of this study, are defined as an expression of organizational routines (NELSON and WINTER, 2005).

Budgeting routines are activities that are an integral part of organizations' short-term planning and control systems (MERCHANT, $1981,1998)$ and their purpose includes planning, coordination, allocation of firm resources, and determination of operational volumes, although they also have a monitoring/control element (EKHOLM and WALLIN, 2011; KIHN, 2011). Although they are regulated by predefined procedures, schedules, and objectives, budgeting routines are subject to unexpected setbacks and difficulties that are inherent to the organizational context - relations between internal departments, delays that exceed information delivery deadlines, changes to standards and regulations, etc. However, the teams responsible must still fulfill firm needs despite these obstacles. To achieve this, processes take place within these teams to adapt, reconfigure, and adjust individual and collective behavior, which, undoubtedly, also change the competencies that people and groups need to enable them to achieve the desired results.

The issue of adaptation and adjustment of organizational routines is specifically dealt with by Feldman (2000) and by Feldman and Pentland (2003) in the form of recursivity between stability and change, emphasizing, on one hand, the institutional aspects of routines (objectives and targets, prescription of the sequence of activities, predetermined deadlines etc.), which are termed the ostensive aspect of the routine, and, on the other hand, movements to accommodate internal changes and to adapt processes and schedules, introduced by the people who engage in the routines and comprise their performative element (FELDMAN, 2000). The issue of recursivity between stability and change in organizational routines was recently revisited (FELDMAN, PENTLAND, D'ADDERIO et al., 2016) and will underpin our analysis of budgeting routines.

In turn, collective work can be generically described as performance in conjunction of the same activity or work process, involving several individuals, in the same or different places and times, and involving interdependence between tasks, coordinated actions, and the possibility of mediated communication (LEPLAT, 2000; CAROLY and BARCELLINI, 2013). To meet these conditions, collective work requires that the individual members share the same objectives, mediation of resources available, and awareness of the restrictions involved in its performance (MICHAUX, 2011). As collective work is repeated over time, attributes and competencies are formed (RETOUR and KHROMER, 2011).

Thus, the motivation behind this investigation lies in the relationship between the dynamics of organizational routines and collective work configurations, which is a relationship that can be found in a number of previous theoretical and empirical studies (FELDMAN, 2003; NELSON and WINTER, 2005; PENTLAND and FELDMAN, 2005; MICHAUX, 2011; PARMIGIANI and HOWARDGRENVILLE, 2011; ALBA and TSOUKAS, 2013). This relationship is the origin for the assumption that organizational routines may constitute environments that are potentially conducive to the presence of work collectives and this relationship also provides the foundation for the research question that this paper attempts to answer: Can the dynamics of corporate budgeting routines constitute an environment that fosters formation and development of collective competencies? The search for answers to this 
question involves an investigation conducted with managers and team members who take part in the corporate budgeting routines of a selection of different organizations, in order to determine and analyze whether it is possible to identify evidence of formation and development of work collectives in these environments. The intention is that the results of the investigation will contribute to closing the knowledge gap related to work collectives and their attributes and competencies.

The theoretical resource used to frame this phenomenon is the concept of Collective Competence itself, which will be used to trace and analyze the most important means by which collective attributes are mobilized in budgeting routines (RETOUR and KHROMER, 2011; MICHAUX, 2011; DEFÉLIX, LE BOULAIRE, MONTIES et al., 2014; LE BOTERF, 2014; MACKE and CRESPI, 2016; SILVA and RUAS, 2016), while the budgeting routines themselves will be analyzed in the light of the concept of organizational routines (NELSON and WINTER, 2005; FELDMAN, 2000, 2003, 2016; PENTLAND and FELDMAN, 2005; PARMIGIANI and HOWARD-GRENVILLE, 2011).

The methodology used in this study comprises two different study phases. Phase one was designed to identify the perceptions with relation to working in groups of 17 work group managers who worked on the budgeting routines of a selection of firms and consisted of interviewing these managers and then conducting a phenomenographic analysis, with particular focus on the processes of collective working configurations in that setting. In the second phase, the results of phase one were crosschecked and analyzed with 20 members of work groups who also worked on budgeting routines at the time.

The most interesting element in the findings of this study was identification of four descriptive categories relating to formation and development of collective competencies in budgeting routines: a) commitment to deliver; b) continuous reconfiguration of routines to improve them; c) shared availability to enable adaptations of routines and structures; $d$ ) construction of networks of relationships with other teams working on different routines, in order to appropriate improvements.

This paper is divided into five sections, including this introduction. The next section covers the theoretical framework employed in analyses of the results, the third describes the methodology used, the results are presented and analyzed in the fourth section, and the fifth section contains final comments.

\section{Collective Competencies and Development of Work Collectives}

Studies about collective competencies began to appear during the 1990s and provoked a relatively large degree of interest over the decades that followed. However, theoretical and empirical exploration of the subject is still in the consolidation phase, as illustrated by the variety of different concepts relating to it, both on the national and international levels (BORENHAM, 2004; MICHAUX, 2011; RETOUR and KROHMER, 2011; ARNAUD and MILLS, 2012; RUAS, SILVA, BECKER et al., 2013; CAROLY and BARCELLINI, 2013; LOUFRANI-FEDIDA and MISSONIER, 2015; MACKE and CRESPI, 2016; SILVA and RUAS, 2016).

Silva (2012) has stated that when dealing with competencies of a collective nature, it is necessary to understand both the context in which work groups work and the ways in which they interact. According to Le Boterf (2003), collective competencies are constructed on the basis of an articulation between mutual relations, which demand individual competencies of the type "know how to cooperate" and "know how to learn", in order to place them at the team's disposal and generate cooperation and learning within the collective. He also claims that the quality of interactions and cooperation can lead to productivity gains. In turn, Boreham (2004) has identified the sense of interdependence that develops within the group as a fundamental element of collective competence, able to overcome the culture of individualism.

Michaux (2011) makes an important contribution with the suggestion that appropriation of the concept of social capital, from the internal perspective of a work group, may be able to explain the positive results of collective action and also possible improvements in the performance of such a group. Thus, relationships, interaction, cooperation, interdependence, and collective learning would be some of the component elements of the social perspective on a work group and may be considered as driving factors of the formation of collective competencies (MICHAUX, 2011). Retour and Krohmer (2011) explored the internal environments of work groups, identifying four attributes of a collective nature that are capable of driving collective competencies, which they labeled: a common frame of reference - the structural element of collective action that is necessary for activity to be performed; a common language, which is an attribute that enables communication to be condensed, thus reducing the time needed for many operations; a collective memory, providing support for current decisions on the basis of past learning; and subjective commitment, which is related to group mobilization in the direction of goals and objectives.

Ruas, Silva, Becker et al. (2013) describe the results of research conducted at five large firms, in which they observed that processes of interaction, cooperation were valued and that knowledge and skills developed within different groups working on projects were shared to solve strategic problems and develop innovations. One important contribution made by that study 
was the finding that these work groups exhibited different stages of work collective development: (a) existence of a group activity; (b) institutionalization of the group activity; (c) formation of attributes of a collective nature through the activity; and (d) evidence of the existence of collective competencies capable of improving the work collective's performance.

In turn, Silva and Ruas (2016) conducted a study designed to identify and analyze collective competencies in the people management practices at a financial firm, observing that approaching the management practices from the organizational routines perspective facilitated analysis of the internal relations between the members of the groups that carried out these routines. This approach enabled them to identify two types of collective competence related to people management routines and the stages of development of these competencies.

Finally, Caroly and Barcellini (2013) argue that it is necessary to distinguish a work group from a work collective. In their view, a work collective is a configuration that achieves superior collective performance to a conventional work group. This superior performance is generally the result of development, within a given group, of competencies associated with a collective type of activity, such as: cooperation, sharing, communication, mutual trust, evaluation of the relationship with the group objective, and others (ARNOUD and FALZON, 2013). Evidently, in addition to the competencies of the individuals who are members of the group, development of collective competencies is dependent on continuous activity that results in the group's internal relations reaching maturity. Construction of the competencies associated with collective activity is one of the central themes of the collective competence approach (BORENHAM, 2004; MICHAUX, 2011; RETOUR and KROHMER, 2011; RUAS, SILVA, BECKER et al., 2013; MACKE and CRESPI, 2016; SILVA and RUAS, 2016).

\section{Organizational Routines: considerations on their dynamics}

Although the first studies of organizational routines and behavior can be attributed to the pioneering work by March and Simon (1958) and Cyert and March (1963), the notion of organizational routines was consolidated by Nelson and Winter (1982), within the Evolutionary Theory perspective, as a way to highlight those organizational elements that are repeated over time. According to Nelson and Winter (2005), technical routines for production of goods, routines for identifying the most important items in inventory, routines for identifying requirements for R\&D investments, and strategies for making decisions on international investments can all be considered examples of organizational routines. Corporate budgeting routines are also a type of organizational routine.

One of the most controversial issues within the debate on this subject, and one that is highly relevant to the present investigation, is related to the dynamics between stability and change of organizational routines. Since repetition is a specific element of routines, it is hard to imagine a routine without repetition; however, the limitations of repetition in unstable and dynamic environments cannot be ignored (BIRTH, RUAS and SILVA, 2017). According to Parmigiani and Howard-Grenville (2011), in the selective and genetic inheritance claimed by Nelson and Winter (2005), routines were conceived as a set of simple rules, standardized procedures, and patterns of behavior that enabled more efficient reaction to the environment and conflict resolution (PARMIGIANI and HOWARD-GRENVILLE, 2011). As a result, the view of organizational routines taken by Nelson and Winter (2005) is considered an example of the capabilities perspective and has been criticized as an excessively normative approach (FELDMAN and PENTLAND, 2005; MICHAUX, 2011). A decisive contribution on what can be described as the flexibility of organizational routines can be found in work by Feldman (2000) and Feldman and Pentland (2003).

Feldman (2000) understands organizational routines to be living processes that can be modified by the action of the agents who carry them out and experience the relationships between the flows expected by the organizational routine and the difficulties that emerge from day to day. In other words, if the routine has an effect different from the effect that is expected of it, its participants should alter it in order to achieve the desired result (FELDMAN, 2000). Thus, if responsibility for a routine is attributed to a group of individuals, the group's "actions" can be classified as relational (FELDMAN, PENTLAND, D'ADDERIO et al., 2016). Working within this perspective, Feldman and Pentland (2003, p. 95) define organizational routines as "[...] repetitive, recognizable patterns of interdependent actions, carried out by multiple actors."

Feldman, Pentland, D'Adderio et al. (2016) value the transformative effects that internal actors' actions have on routines, observing that changes to routines are not only dependent on intervention by external factors, but are also subject to changes generated internally. Feldman, Pentland, D'Adderio et al. (2016) refer to this wider dynamism as "dynamic routines", which is a concept that does not only consider what happens "inside" the routines, but also their ecology, i.e. their mutual interdependence.

Clearly, the organizational routines framework, and especially its ostensive and performative aspects, offers great potential for contributing to analysis of the activity of the different groups responsible for the budgeting routines examined herein. 


\section{Organizational Routines as a locus of collective configurations}

Within the literature on collective competencies, Michaux (2011) positions organizational routines as the point of interface between the individual, collective, and organizational dimensions of corporate competencies. She considers routines to be tacit, with origins in experiences and processes of collective learning over time, as part of group practices (MICHAUX, 2011). Defining organizational routines as the result of collective learning may be related to one of its seminal principals: in routines, the collective takes priority over individual interests and initiatives (NELSON and WINTER, 2005). However, according to Feldman and Pentland (2003), this predominance of the collective over the individual does not interfere with the processes that lend flexibility to routines, which may be altered or maintained, and neither does it avoid the need for periodic review and reconfiguration of the distribution and coordination of actions between the different actors, in particularly at times marked by difficulties and unexpected setbacks (FELDMAN and PENTLAND, 2003; PARMIGIANI and HOWARD-GRENVILLE, 2011; FELDMAN, 2016). Feldman and Pentland (2003) also note that organizational routines are structured on the basis of collective not individual routines; thus, when the "multiple participants" of routines introduce different interpretations of them, this diversity is moderated by the institution's needs and conditions, such as objectives, schedules, and corporate directives.

Thus, consolidation of routines is necessarily a matter of dynamic and, very often, complex, interaction between the ostensive (institutional directives) and performative (adjustments and reconfigurations) aspects of organizational routines. Through this exercise, the work groups responsible for conducting routines become the actors in a process of collective learning. One of the results of this process is development of attributes/competencies of a collective nature, such as commitment to the demands of the routines, adaptation, sharing, relationship building and communication, mutual trust, improvisation, systemic viewpoints, and others (ARNOUD and FALZON, 2013). Finally, with relation to the performance of groups, it should be pointed out that certain authors in the literature distinguish a "work group" from a "work collective", considering that the latter is a more advanced configuration of the former, because it achieves superior collective performance, which is very often the result of attributes/competencies of a collective nature (CAROLY and BARCELLINI, 2013).

The observations set out above were used as a foundation for an examination of formation of collective competencies in the locus of organizational routines.

\section{METHODOLOGY}

This is an empirical study and its objective is to contribute to knowledge on the formation of collective competencies in teams (work groups), focusing on the Organizational Budgeting Routines of a selection of different firms.

The first phase of this study employed a phenomenographic method, in line with the theoretical and methodological proposals of Marton and Booth (1997), and was based on interviews with managers of work groups working on budgeting routines. Phase two employed analysis of multiple cases to attempt to understand the category of actors who had not been included in the previous phase: the remaining members of the work groups. The research conducted in the field thus comprised two different phases and a total of 37 interviews, which were conducted at 24 different firms and are specified in Box 1.

The theoretical and methodological approach of phenomenography is founded on the qualitatively varied experiences of different people with relation to a given phenomenon. A secondary perspective is adopted, from which the aim is to identify both the perceptions of the people who underwent the experiences of interest and the significance that they attribute to them. Thus, working with a collection of reports of the different ways in which different people perceive the phenomenon through their practices, representative categories are identified for these subjects' conceptions; these categories/conceptions represent constituent elements of the phenomenon studied, revealing a theoretical map of the collective consciousness (MARTON, 1981; MARTON and BOOTH, 1997; SANDBERG, 2000). A phenomenographic analysis also identifies the explanatory dimensions and critical aspects that define and explain the categories' distinguishing features. The categories and dimensions are presented systematically in a map of the results space, known as the outcomespace (COLLIER-REED and INGERMAN, 2013).

Since phenomenography requires that samples be as varied as possible (SANDBERG, 2000; AKERLIND, 2005), individual interviews were conducted with managers of work groups from 17 different firms. This phase was conducted during the period from September 11 to November 16, 2014 (Box 1: part 1). A semistructured script was used and interviews lasted from 30 to 40 minutes. In this regard, it was observed that prior knowledge of the fundamentals of finance and budgeting 
that underpin these routines, both on the part of the researcher conducting the interviews and of the interviewees, helped to substantially reduce the time taken to conduct the interviews.

Transcripts were analyzed in accordance with phenomenographic recommendations (MARTON and BOOTH, 1997; AKERLIND, 2005), especially with respect to decontextualization of the subjects. Initially, all transcripts were read and the most significant similarities that stood out were noted. Next, each transcript was read in much greater detail. The similarities thus identified enabled selection of excerpts from the interviews (quotes) which illustrated the categories identified and helped in the process of assimilation of the dimensions that explain the context in which the routines are enacted.

The main findings of phase one were evaluated and debated (including at an academic conference), revealing a need to extend the research to encompass the perceptions of the members of work groups who conduct the budgeting routines, in order to avoid restricting the research findings to the opinions of managers. A second phase involving multiple case studies was therefore designed and carried out (GHAURI, 2004).

When choosing subjects for the second sample, work groups in which the managers interviewed in the first phase work were avoided. The sample selected comprised 20 members of other groups that work on budgeting routines, 14 of whom were selected from 7 firms not previously sampled. The second phase of interviews was designed to investigate the existence of difficulties with consolidation of work collectives, such as, for example, intra-team conflicts. Thus, between March 23 and July 21, 2016, the outcomespace map was presented and explained to the 20 team members (Box 1: part 2), in interviews using a new semistructured interview script. This script requested interviewees to describe experiences they had had that were related to the content of the outcomespace map.

Analysis of the multiple cases from the second phase of data collection was conducted in a similar manner to the phenomenographic analysis, with the addition of a re-reading step, dedicated to analysis of the nature of the new findings (Figure 1).

The final phase of the study was to construct a Consolidated Results Table (Figure 2), specifically dedicated to systematization of the results of the analysis. That table therefore covers the most important issues related to processes capable of driving formation and development of collective competencies.

Box 1

Interviewees

\begin{tabular}{|c|c|c|c|c|c|}
\hline \multicolumn{3}{|c|}{ Part 1: Phase 1 of the study } & \multicolumn{3}{|c|}{ Part 2: Phase 2 of the study } \\
\hline \multicolumn{3}{|c|}{ Interviewees: Team managers } & \multicolumn{3}{|c|}{ Interviewees: Team members } \\
\hline Subject & Business sector & Gender & Subject & Business sector & Gender \\
\hline 1 & Pharmaceuticals-Cosmetics & Male & 18 & Airline Industry & Female \\
\hline 2 & Logistics & Male & 19 & Oil and Gas & Female \\
\hline 3 & Property Development & Female & 20 & Oil and Gas & Female \\
\hline 4 & Pharmaceuticals-Cosmetics & Male & 21 & Pharmaceuticals-Cosmetics & Female \\
\hline 5 & Mining & Male & 22 & Pharmaceuticals-Cosmetics & Female \\
\hline 6 & Oil and Gas & Female & 23 & Pharmaceuticals-Cosmetics & Female \\
\hline 7 & Oil and Gas & Female & 24 & Mining & Female \\
\hline 8 & Pharmaceuticals-Cosmetics & Male & 25 & Pensions & Female \\
\hline 9 & Telecommunications & Male & 26 & Pensions & Female \\
\hline 10 & Telecommunications & Male & 27 & Telecommunications & Male \\
\hline 11 & Telecommunications & Male & 28 & Insurance & Male \\
\hline 12 & Pharmaceuticals-Cosmetics & Male & 29 & Food and Drink & Male \\
\hline 13 & Food and Drink & Female & 30 & Oil and Gas & Male \\
\hline 14 & Oil and Gas & Female & 31 & Oil and Gas & Female \\
\hline 15 & Telecommunications & Male & 32 & Telecommunications & Female \\
\hline 16 & Pharmaceuticals-Cosmetics & Female & 33 & Telecommunications & Male \\
\hline \multirow[t]{4}{*}{17} & Finance and Insurance & Male & 34 & Telecommunications & Male \\
\hline & & & 35 & Music Industry & Female \\
\hline & & & 36 & TV and Journalism & Male \\
\hline & & & 37 & Mining & Female \\
\hline
\end{tabular}

Source: Elaborated by the authors. 
Figure 1

Study Design

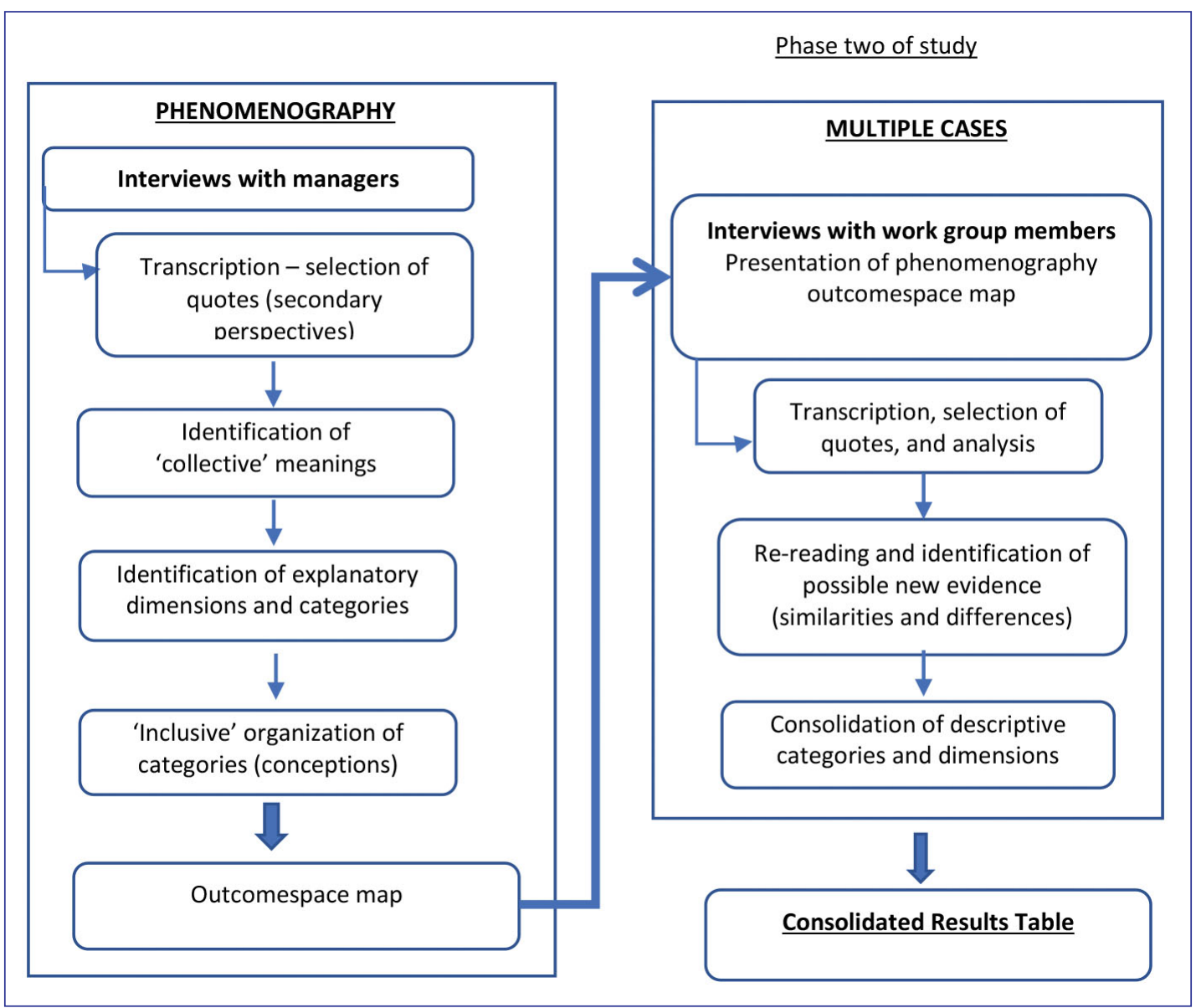

Source: Elaborated by the authors.

\section{Main Results and Contributions}

Analysis of the data identified four descriptive categories of the phenomenon related to formation of collective competencies in the context of budgeting routines: a) commitment to deliver; b) continuous reconfiguration of routines, to improve them; c) shared availability of team members, to enable adaptation of routines and structures; and d) construction of networks of relationships with other teams working on different routines, in order to appropriate improvements. These descriptive categories are founded on explanatory dimensions that differentiate them: i) a dynamic formed by the relationship between the ostensive and performative aspects of the routines; ii) disturbances that upset the routines' schedules of activities; iii) the nature of the internal relations within the work group; and iv) the group's degree of autonomy.

The Consolidated Results Table - Figure 2 - contains both the descriptive categories and the explanatory dimensions. The descriptive categories for the phenomenon of formation of collective competencies in the context of budgeting routines are in the columns and the explanatory dimensions are on the rows. 
Figure 2

\section{Consolidated Results Table}

\begin{tabular}{|c|c|c|c|c|}
\hline $\begin{array}{l}\text { Descriptive } \\
\text { categories }\end{array}$ & $\begin{array}{l}\text { Commitment } \\
\text { to deliver }\end{array}$ & $\begin{array}{l}\text { Reconfiguration } \\
\text { of routines }\end{array}$ & Shared availability & Building relationship networks \\
\hline $\begin{array}{l}\text { Results of } \\
\text { phase one, } \\
\text { conducted } \\
\text { with } \\
\text { managers: }\end{array}$ & $\begin{array}{l}\text { The teams perform } \\
\text { uniformly to meet } \\
\text { challenges and make } \\
\text { extra effort to ensure } \\
\text { that the group's } \\
\text { "deliveries" are } \\
\text { made according to } \\
\text { the ideal routine set } \\
\text { out in the budgeting } \\
\text { calendar. They hit their } \\
\text { deadlines. }\end{array}$ & $\begin{array}{l}\text { The teams make changes } \\
\text { to routines to optimize } \\
\text { work and to continuously } \\
\text { improve processes. } \\
\text { Thus, efforts to obtain } \\
\text { greater efficiency from } \\
\text { the routines emerge from } \\
\text { within the teams. }\end{array}$ & $\begin{array}{l}\text { The teams try to be able to } \\
\text { adapt to adverse situations, in } \\
\text { order to organize themselves in } \\
\text { accordance with the situation } \\
\text { (they have a fluid characteristic). } \\
\text { They engage in collective } \\
\text { redundancy practices (desk- } \\
\text { swapping, backups, taskforces), } \\
\text { that mean that management } \\
\text { work in a cooperative manner } \\
\text { to redistribute responsibilities in } \\
\text { synergy. }\end{array}$ & $\begin{array}{l}\text { The teams build relationship } \\
\text { networks and attempt to see } \\
\text { things from the point of view } \\
\text { of adjacent departments and/ } \\
\text { or internal customers. This } \\
\text { therefore involves not just their } \\
\text { own teams, but the whole } \\
\text { organization. } \\
\text { The teams exhibit autonomy of } \\
\text { intragroup interaction and are } \\
\text { concerned with exposure and } \\
\text { recognition. }\end{array}$ \\
\hline $\begin{array}{l}\text { Results of } \\
\text { phase two, } \\
\text { conducted } \\
\text { with team } \\
\text { members: }\end{array}$ & $\begin{array}{l}\text { In general, demands } \\
\text { are not questioned } \\
\text { or refused, even } \\
\text { when unexpected. } \\
\text { This takes place in } \\
\text { a scenario in which } \\
\text { long working hours } \\
\text { and interdependence } \\
\text { with other firm } \\
\text { departments are the } \\
\text { norm. }\end{array}$ & $\begin{array}{l}\text { 'Changing routines and } \\
\text { making them more } \\
\text { efficient' is a behavior that } \\
\text { is necessary for teams to } \\
\text { survive within this activity } \\
\text { and one that they have } \\
\text { internalized. } \\
\text { "Processes built from the } \\
\text { bottom up" [E30]. } \\
\text { They describe many } \\
\text { examples that provide } \\
\text { evidence of improvement to } \\
\text { routines over recent years, } \\
\text { enabling excessive working } \\
\text { hours to be reduced. }\end{array}$ & $\begin{array}{c}\text { They try to avoid allowing } \\
\text { routines to break down in } \\
\text { emergency situations. } \\
\text { They collaborate with each } \\
\text { other. } \\
\text { They also point out that the } \\
\text { opportunity for learning is } \\
\text { motivational. } \\
\text { One team member's utterances } \\
\text { indicated that there was a } \\
\text { need to overcome a "lack of } \\
\text { trust" within the team and } \\
\text { internal competitiveness before } \\
\text { collective practices could be } \\
\text { adopted in her department. }\end{array}$ & $\begin{array}{l}\text { The team members also state } \\
\text { that they have autonomy to } \\
\text { interact directly with other } \\
\text { departments (whether with } \\
\text { managers or their points of } \\
\text { reciprocal contact). } \\
\text { Reconfigurations of routines or } \\
\text { modifications to instruments } \\
\text { are decided in conjunction } \\
\text { with other departments. }\end{array}$ \\
\hline $\begin{array}{l}\text { Explanatory } \\
\text { Dimension: } \\
\text { Adjustment } \\
\text { between } \\
\text { performative } \\
\text { and ostensive } \\
\text { aspects }\end{array}$ & $\begin{array}{l}\text { The teams fulfill } \\
\text { demands (whether } \\
\text { expected or } \\
\text { unexpected). This } \\
\text { commitment is seen } \\
\text { as a result of the } \\
\text { team rather than of } \\
\text { individual members. } \\
\text { Schedules provide a } \\
\text { common reference } \\
\text { (ostensive). }\end{array}$ & $\begin{array}{l}\text { The teams rethink and } \\
\text { modify the budgeting } \\
\text { routines, focusing on } \\
\text { tasks to make them } \\
\text { more efficient. This } \\
\text { includes efforts to reduce } \\
\text { unnecessary work and } \\
\text { reworking. }\end{array}$ & $\begin{array}{l}\text { Teams work with a focus on } \\
\text { sharing and on (re)distribution } \\
\text { of responsibilities to change or } \\
\text { maintain budgeting routines. } \\
\text { They are aware of their } \\
\text { interdependence. } \\
\text { Backups are important to } \\
\text { avoid exclusive "owners" of } \\
\text { information. }\end{array}$ & $\begin{array}{l}\text { Teams change the routines } \\
\text { in search of performance, } \\
\text { working from the underlying } \\
\text { premise that they must } \\
\text { be validated by and/or } \\
\text { coordinated with adjacent } \\
\text { routines or other departments. } \\
\text { There is also a concern } \\
\text { for advantages for other } \\
\text { departments. } \\
\text { A need to understand } \\
\text { information related to other } \\
\text { departments was mentioned. }\end{array}$ \\
\hline $\begin{array}{l}\text { Explanatory } \\
\text { Dimension: } \\
\text { Schedule of } \\
\text { activities }\end{array}$ & $\begin{array}{l}\text { Long Working Hours. } \\
\text { The team is committed } \\
\text { and accepts } \\
\text { unscheduled demands, } \\
\text { preparing additional } \\
\text { reports, spreadsheets, } \\
\text { etc. for extraordinary } \\
\text { meetings. } \\
\text { "They stay at work, } \\
\text { order pizza, and carry } \\
\text { on working". } \\
\text { Collective } \\
\text { commitment. } \\
\text { The team members } \\
\text { claim that they have } \\
\text { flexible (informal) } \\
\text { working hours. }\end{array}$ & $\begin{array}{l}\text { Long Working Hours. } \\
\text { Reality is dynamic and so } \\
\text { are firms. The long working } \\
\text { hours are the primary } \\
\text { motivation for teams to try } \\
\text { to optimize the routines. } \\
\text { "They stay at work, } \\
\text { order pizza, and carry on } \\
\text { working". } \\
\text { Excerpts illustrate episodes } \\
\text { that confirm reductions to } \\
\text { excessive working hours } \\
\text { during budgeting cycles. }\end{array}$ & $\begin{array}{l}\text { Long Working Hours and periods } \\
\text { of understaffing motivate the } \\
\text { teams to remain flexible and } \\
\text { self-organize (fluidity). } \\
\text { "They stay at work, order pizza, } \\
\text { and carry on working". } \\
\text { Extra work during "peak" } \\
\text { periods and standing-in for } \\
\text { other team members can } \\
\text { provide opportunities for } \\
\text { learning. }\end{array}$ & $\begin{array}{l}\text { Since deadlines are tight, they } \\
\text { claim that there isn't time for } \\
\text { management to monitor their } \\
\text { activities and interactions with } \\
\text { other departments. } \\
\text { "They stay at work, order pizza, } \\
\text { and carry on working". }\end{array}$ \\
\hline
\end{tabular}




\begin{tabular}{|c|c|c|c|c|}
\hline $\begin{array}{l}\text { Descriptive } \\
\text { categories }\end{array}$ & $\begin{array}{l}\text { Commitment } \\
\text { to deliver }\end{array}$ & $\begin{array}{l}\text { Reconfiguration } \\
\text { of routines }\end{array}$ & Shared availability & Building relationship networks \\
\hline $\begin{array}{l}\text { Explanatory } \\
\text { Dimension: } \\
\text { Nature of } \\
\text { relations }\end{array}$ & Collaborative & Collaborative & \begin{tabular}{|c|} 
Collaborative. \\
During phase two, an \\
understanding emerged \\
that collaboration may be \\
deliberative, but can also be \\
seen as "something necessary" \\
to achieve the team's objectives.
\end{tabular} & $\begin{array}{l}\text { Intragroup and intergroup } \\
\text { collaboration. }\end{array}$ \\
\hline $\begin{array}{l}\text { Explanatory } \\
\text { Dimension: } \\
\text { Autonomy }\end{array}$ & & $\begin{array}{l}\text { Traits of autonomy can } \\
\text { be identified, since } \\
\text { reconfiguration of routines } \\
\text { is of endogenous origin, } \\
\text { bearing in mind that } \\
\text { agency is perceptible. } \\
\text { "Bottom up". }\end{array}$ & $\begin{array}{c}\text { Autonomy is primarily } \\
\text { demonstrated in relation to the } \\
\text { intragroup interest in sharing } \\
\text { learning and discoveries. }\end{array}$ & $\begin{array}{c}\text { The teams see themselves } \\
\text { as autonomous and state } \\
\text { that they interact with } \\
\text { their relationship networks } \\
\text { independently. } \\
\text { It may be necessary to } \\
\text { develop new team members' } \\
\text { autonomy. }\end{array}$ \\
\hline
\end{tabular}

Source: Elaborated by the authors.

\section{Commitment to deliver}

This category deals with the work groups' efforts to meet the demands of the budgeting cycles in a collaborative manner. The interviewees consider that their work groups are committed to meeting the demands of annual budgeting cycles and/or the revisions and alterations that follow and that they meet these deadlines even if they have to do extra work to do so. This commitment, "... a force that binds an individual to a course of action of relevance to a target ..." (MEYER and HERSCOVITCH, 2001), is collective and shared, so that fulfillment of tasks is seen as a team and not an individual achievement (NELSON and WINTER, 2005). The theory of a dynamic interface between the ostensive and performative aspects of routines (FELDMAN, 2000,2003 ) is of help in understanding that work groups need to act to resolve new demands created by extra activities (performative), while complying with institutional demands (ostensive). There were several references to collective effort by groups, involving working into the night, or even the early hours, and at weekends in order to meet demands, as illustrated in interviews $\mathrm{E} 30$ and $\mathrm{E} 11$ :

[...] part of the budget involves a lot of work, we call it the ad hoc items, which are unplanned elements that come up and mean that we have to conduct analyses before we can deliver. [E30].

[...] everything was changed overnight, and the deadline for presentation to the board was the day after. So we had to deliver everything the same day and we came in at 8 in the morning and only left at midday the next day. [E11].

This situation makes it necessary to adjust routines and demands unplanned activities, which causes problems for the schedule of activities that were planned for the group.

The explanatory dimensions associated with this category are, as already mentioned, the adjustment between performative and ostensive aspects, and also the nature of relations, which expresses the collaborative characteristic of relations between the members of the work group: "everybody ends up helping, because we have an objective in common, which is to deliver the project" [E34]. Even if one of the group members questions the extra tasks, there is no question of "not delivering": "Commitment, definitely. We get our deadlines top-down. You might even question them: sort of, 'Shoot! Why does this have to be for tomorrow? It makes no sense', but it doesn't occur to us not to deliver" [E22].

This attitude to commitment with delivery illustrates the attribute "subjective commitment" (RETOUR and KROHMER, 2011, p. 50), which may be a foundation of collective competence.

Also notable are excerpts from interviews that reveal situations in which former members of these groups did not achieve this level of commitment and, because of this, soon moved departments or left the firm. As possible motivating factors for these professionals' commitment, the interviewees mentioned the flexibility of working hours during calmer periods, although 
there did not appear to be any link to extra remuneration or a formal system for "banking" overtime (flexi-time), as was also observed by Silva and Ruas (2016).

\section{Reconfiguration of routines}

It appears to be a principle held in common by these groups that routines should/could be "improved and reconfigured" continuously. In other words, these groups appear to go beyond the ostensive perspective of routines, since they do not seem to limit themselves to meeting the institutional demands on the routines. This process originates in initiatives by the teams themselves - which was perceived by the managers and confirmed by the team members, revealing the performative aspect of these routines (FELDMAN, 2000, 2003).

Interviewee E30 claimed that these "processes are built from the bottom up", while interviews E19, E20, E27, and E35 illustrated positive impacts on activity schedules, since their teams have gradually managed to reduce excessively-long working days: "And each year we have indeed reduced the number of overtime hours worked [...] There have been budgets when we had to sleep here, had to stay here until the next day or the early hours of the morning, but now we don't have to go that far anymore" [E19]. These actions suggest that the group works collaboratively to solve the complex problems of their jobs and learn through practice (ODELIUS, ABBAD, RESENDE JUNIOR et al., 2011).

One explanatory dimension that is relevant to this category is the groups' autonomy. It is understood that they have the "agency" to modify routines (GIDDENS, 1984; FELDMAN, 2000), through a collective approach, as manager E16 explained: "In general they repeat what is routine, but nevertheless they are sufficiently analytical to be critical if something can be improved. So they try, and I encourage them, to try and see what we can do to increase productivity and get things done in less time".

Thus, the teams take shared and collaborative initiatives to modify/adapt/recreate their budgeting routines, and are able not just to reduce the excessive working hours, but also to achieve efficiency and quality gains. As Arnoud and Falzon (2013) point out, the superior performance of some groups involves cooperation, communication, and mutual trust. These professionals engage in creation of new patterns of behavior to perform their routines, on the groups' own initiatives, irrespective of external influences. They therefore manifest an internal dynamic developed by the groups themselves (FELDMAN, 2016).

\section{Shared availability}

This descriptive category deals with individual and collective readiness for self-organization, with the objective of achieving better performance from routines, especially when unexpected contingencies come up in their budgeting cycles. In addition to their activities, the responsibilities of each team member are also considered. Within this process, the teams develop and share awareness of the interdependence of activities and seek means of making their structure more "fluid" through redundancy practices - desk-swapping and backups - in which team members learn each other's tasks. This structural flexibility within the teams promotes work continuity and quality and avoids routines from suffering failures provoked by extra demands or individual team members' problems. As such, these professionals embody Le Boterf's (2014) comments on "wearing other people's shoes", as can be observed in excerpts from the interviews:

[...] We have started to look at this issue of holiday cover, which I think is the best way to start to learn somebody else's job. It is extremely important to provide backup. Because each activity must always have a backup. Because you can't have a team where someone is doing a job that only they know how to do. [E20].

Sometimes, we try to change places to get multitasking into the team. These days we have gained a good deal of experience with the numbers and we have been able to considerably shorten the working day during the budgeting season. [E30].

The collaborative nature of the practice of providing backup was also identified by interviewee E19 as motivational and as an alternative to formal training. Other interviews also provided evidence of a deliberative aspect of "team solidarity": "it really does end up creating a closer relationship" [E24]; "everybody helps each other because there's a lot of pressure" [E20]. In other words, there is an awareness within the team that this collaboration is indispensable because jobs are interdependent: 
We have to be very closely in tune with each other, because any changes that the people in spending make will have an impact, will affect cash flow, available capital [...]. So, if the team is not in tune, if they don't talk to each other... That's why sometimes things don't match up [...]. I cause consequences for someone, and someone also causes consequences for me, so this collective here works well, even when we're recruiting, we try to find people with this profile. [E19].

Although predominant, this is not an absolute characteristic, since, three of the respondents stated that they did not have redundancy practices at the firms where they work, but, even so, agreed "in theory" with this idea or had seen it used at previous employers. However, interviewee E18 offered a different view from the others. In her opinion, a "lack of trust" in each other (fear that someone else will do the job better) creates limitations that prevent adoption of practices of redundancy and self-organization:

I think that people often think "oh, no I'm not going to show him what I do because he will do it better than me and that could be bad for me, I could be sacked, they could give me the freeze [...] for example: I have someone who only takes care of inventory; this person is always complaining about being overloaded [...]. He doesn't do that [does not adopt redundancy] because he knows that he has all of the information to himself [...]. But I think it ends up creating a hidden competition. It is a competition to protect yourself, from fear of being replaced. [E18].

These statements by E18 puts the issue of "trust in the team" as a powerful mediator in the category Shared Availability and confirm arguments made by Edmonson (1999, p. 375), according to whom "building trust in the work group is an 'ingredient' for creating an atmosphere of psychological security", since it can represent a shared belief, through which the participants in a group tacitly feel safe to express themselves without fear of punishment or rejection (EDMONSON, 1999). Indeed, as observed in interview E18, mutual trust is a key element in construction of collective competencies (MICHAUX, 2011).

\section{Building relationship networks}

The category Building Relationship Networks refers specifically to attempts to understand the point of view of adjacent departments and internal customers. It is related to the fact that management understand that teams must look beyond their own routines and their own team; conceiving a sense of "belonging to an organization" to build relationships that facilitate exchange of information with other departments and thereby obtain improvements in the performance of routines that involve these other departments. This inclination is explained by the institutional nature of budgeting routines; since they are part of an ecology of Organizational Routines, budgeting routines affect and are affected by other routines (FELDMAN, PENTLAND, D’ADDERIO et al., 2016).

This is a department where you have a great deal of interaction with other departments in the firm. So, we demand a lot from other departments in the firm [...] you have the corporate budget [...] and [...] local budgets and you get information from other departments in the business to be able to do them. We were a major source of consolidation. So we would create, for example, the spreadsheets that would be filled in, we set up the system so that the departments can input to it [...] we are going to do it this way: "what do you agree with? What don't you agree with?" [E24] (our emphasis).

In the dimension of adjustment between the performative and ostensive aspects, observation of adjacent routines expresses awareness of and concern for the mutual advantages achieved through initiatives to modify and improve the routines. In parallel, the nature of intergroup relations is also collaborative, illustrated by the absence of conflicts between individuals working in different routines. The team members agree with the opinions of the managers and emphasize that their autonomy in relationships with people from other departments is very often possible with higher levels of the hierarchy: "I would go straight to the manager [of another department] and set up a meeting to present the numbers, to go over them, with the manger [...] you end up getting free access to the managers, particularly during this phase" [E37]. It is notable that this interaction between agents from multiple different routines can reinforce the group's own impressions of dealing with situations that must be dealt with within a process-based perspective, while in flux (CERRETTO and DOMENICO, 2016).

The relationship networks' positive and mutual impact on different routines can be observed in the following: 
For example, we changed our system [process] of investment controls. [...] last year [...] we said "no, it's not working for us or for Marketing, let's build a new one, but let's build it together". So that's what we did, and we tried to listen to what they thought could be improved. Of course we could have done it [alone][...], but no, we tried to listen to their opinions [E23].

This combination of descriptive categories and explanatory dimensions defines and elucidates the theoretical map of collective consciousness, itself constructed on the basis of analysis of the information obtained from managers and from members of the work groups that work on budgeting routines. Within the complex context of corporate budgeting routines, in which there are urgent demands and involvement of many different departments, the descriptive categories emerging from the phenomenographical analysis can be considered as, predominantly, aligned with what is claimed in the literature on collective competencies, especially with regard to teams' transcendence of individual competencies (RETOUR and KROHMER, 2011) and to achieving a level of performance that is greater than the sum of the individual competencies (LE BOTERF, 2014).

\section{FINAL COMMENTS}

The objective of this study was to identify processes that form collective competencies in work groups that work on budgeting routines. To achieve this, we undertook a qualitative study that first surveyed the perceptions of these routines of managers from a selection of different firms (phase one) and then investigated the perceptions of members of work groups that conduct these routines (phase two). The main findings of this study contribute both to the academic debate and to management practice within the organizational environment.

Initially, it should be noted that using the concept of organizational routines as an analytical frame of reference made it possible to examine the principal processes used in corporate budgeting, with an emphasis on the dynamics of recursivity between their ostensive and performative aspects and on the predominance of collective configurations in relation to individual initiatives (FELDMAN, 2003). It was, therefore, confirmed that the organizational routines theory, to which new and important theoretical and empirical contributions have been added, now appears to offer great potential for use as an analytical reference in important corporate processes, both within an academic perspective - such as, for example, for identification of the forms of recursivity between ostensive and performative aspects of organizational processes -, and from a management point of view - with management options for the case of work collectives, both of which are subjects covered in this paper.

Second, the explanatory category Reconfiguration of Routines, which is highlighted through the groups' initiatives to improve their performance, provides a clear example of how organizational routines can host and drive attributes and competencies of a collective nature. Recurrence over time of these adaptations - oscillating between modifications, proposed as part of initiatives for improvement, and stability - demands adjustments to the activities of participants, in terms of greater interdependence between group members and in terms of formation of attributes/competencies of a collective nature, mutual collaboration, sharing of skills and knowledge, commitment to deliver, etc. (RETOUR and KHROMER, 2011). Thus, the process from which the explanatory category Reconfiguration of Routines originates can result in development of competencies of a collective nature, such as the capacity to adapt to change or sharing of responsibilities within the group.

Third, the path taken by this study and its main results emphasize the processes that form attributes and competencies of a collective nature within budgeting routines. Considering that these attributes and competencies can take on different configurations and natures depending on the environments in which they are constructed and the characteristics and paths of the organizations that form them, they may be difficult to replicate in other environments. In other words, they are specific to the organization and the setting in which they are created. In turn, the processes of collective competence formation may be adaptable to other organizations, assuming they are intermediated by the concept of organizational routines, as observed in this paper. This would be the case, for example, of appropriation of the process of adjustment and reconfiguration of routines, as a form of identifying the formation of attributes of a collaborative nature, mutual trust, and commitment, through which collective competencies are constituted. Therefore, the systematization of processes capable of forming and developing attributes and competencies in work groups appears to be knowledge of relevance to management of corporate routines in general and also to high-level people-management professionals. 
Furthermore, one important contribution made in this study is application of the phenomenographical method (which is a theoretical and methodological approach from the field of Education) to Organizational Studies. Using this method, conceptions identified from varied professionals' experiences of a single phenomenon can be reconstructed on a wide spectrum in the organizational context. It should also be considered that evidence was found for the practical applicability of the outcomespace map, constructed by systematization of conceptions/categories, within the organizational context. Indeed, phenomenography enabled the dynamics investigated to be captured and understood through categories that are the interviewee's conceptions of the phenomenon investigated.

It is worth emphasizing the small number of studies examining the issue of collective competence in the context of organizational routines. Undoubtedly, availability of other work on the subject would have enabled the analyses presented here to be extended and deepened. This is one considerable limitation of this investigation. For that very reason, the suggestion for future empirical studies must be to replicate the approach employed herein, dealing with construction of collective competence in other types of organizational routines. 


\section{REFERENCES}

AKERLIND, G. S. Variation and commonality in phenomenographic research methods. Higher Education Research \& Development, v. 24, n. 4, p. 321-334, Nov. 2005.

ALBA, D. D.; TSOUKAS, H. Understanding the (re)creation of routines from within: a symbolic interactionist perspective. Academy of Management Review, v. 38, n. 2, p. 181-205, 2013.

ARNAUD, N.; MILLS, C. E. Understanding interorganizational agency: a communication perspective. Group \& Organization Management, v. 37, n. 4, p. 452-485, 2012.

ARNOUD, J.; FALZON, P. Changement organisationnel et reconception de l'organisation: des ressources aux capabilités. Activités, v. 10, n. 2, p. 109-113, 2013.

BOREHAM, N. A theory of collective competence: challenging the neo-liberal individualisation of performance at work. British Journal of Educational Studies, v. 52, n. 1, p. 5-17, Mar. 2004.

BOREHAM, N. Competence as collective process. In: CATTS, R.; FALK, I.; WALACE, R. (Eds.). Vocational learning: innovative theory and practice. Dordrecht: Springer, 2011. p. 77-91. 14v.

CAROLY, S.; BARCELLINI, F. Le développement de l'activité collective. In: FALZON, P. Ergonomie Constructive. France: PUF, 2013. Available at: <https://hal.archives-ouvertes.fr/halshs-00860638/document>. Accessed on: Sept. 08, 2017.

CERRETTO, C.; DOMENICO, S. M. R. Mudança e Teoria Ator-Rede: humanos e não humanos em controvérsias na implementação de um centro de serviços compartilhados. Cadernos EBAPE.BR, Rio de Janeiro, v. 14, n. 1, p. 83-115, 2016.

COLLIER-REED, B.; INGERMAN, Å. Phenomenography: from critical aspects to knowledge claim. In: HUISMAN, J.; TIGHT, M. (Ed.). Theory and method in higher education research. Emerald Group, 2013. p. 243-260. (International Perspectives on Higher Education Research, v. 9).

CYERT, R. M., MARCH, J. G. A behavioral theory of the firm. PrenticeHall: New Jersey, 1963.

DEFÉLIX, C. et al. La compétence collective dans le contexte de la globalisation du management: retrouver le lien avec la performance. @ GRH, n. 2, p. 31-50, 2014.

EDMONSON, A. Psychological safety and learning behavior in work teams. Administrative Science Quarterly, n. 2, p. 350-383, 1999.

EKHOLM, B.; WALLIN, J. The impact of uncertainty and strategy on the perceived usefulness of fixed and flexible budgets. Journal of Business Finance \& Accounting, v. 38, n. 1-2, p. 145-164, Jan./Mar. 2011.

FELDMAN, M. S. Routines as process: past, present, and future. In: HOWARD-GRENVILLE, J. et al. Organizational Routines: how they are created, maintained, and changed. UK: Oxford University Press, 2016. p. 23-46.

FELDMAN, M. S. A performative perspective on stability and change in organizational routines. Industrial and Corporate Change, v. 12, n. 4, p. 727-752, 2003.

FELDMAN, M. S. Organizational routines as a source of continuous change. Organization Science, v. 11, n. 6, p. 611-629, 2000.
FELDMAN, M. S. et.al. Beyond routines as things: introduction to the special issue on routine dynamics. Organization Science, v. 27, n. 3, p. 505-513, May/June 2016.

FELDMAN, M. S; PENTLAND, B. T. Reconceptualizing organizational routines as a source of flexibility and change. Administrative Science Quarterly, v. 48, n. 1, p. 94-118, 2003.

GHAURI, P. Designing and conducting case studies in international business research. In: MARSCHAN-PIEKKARI, R.; WELCH, C. Handbook of qualitative research methods for international business. Cheltenham: Edward Elgar, 2004.

GIDDENS, A. A constituição da sociedade. 2. ed. São Paulo: Martins Fontes, 1984.

KIHN, L. How do controllers and managers interpret budget targets? Journal of Accounting \& Organizational Change, v. 7, n. 3, p. 212 236, 2011.

LE BOTERF, G. Construire les compétences individuelles et collectives: le modèle: agir avec compétence en situation - Les réponses à plus de 100 questions. Paris: Editions Eyrolles, 2014.

LE BOTERF, G. Desenvolvendo a competência dos profissionais. Porto Alegre: Artmed, 2003.

LEPLAT, J. Compétences individuelles, compétences collectives. Psychologie du Travail et des Organisations, v. 6, n. 3-4, p. 47-73, 2000.

LOUFRANI-FEDIDA, S.; MISSONIER, S. The project manager cannot be a hero anymore! Understanding critical competencies in projectbased organizations from a multilevel approach. International Journal of Project Management, v. 33, n. 6, p. 1220-1235, 2015.

MARCH, J. G.; SIMON, H. A. Organizations. New York: Wiley, 1958.

MACKE, J.; CRESPI, K.M. "One swallow does not make a summer": the development of an instrument for measuring collective competences in information technology teams. SAGE Open, p. 1-11, Apr./June 2016.

MARTON, F.; BOOTH, S. A. Learning and awareness. Mahwah: Lawrence Erlbaum, 1997.

MARTON, F. Phenomenography: describing conceptions of the world around us. Instructional Science, v. 10, n. 2, p. 177-200, 1981.

MERCHANT, K. A. Modern management control systems: text and cases. London: Prentice Hall, 1998.

MERCHANT, K. A. The design of the corporate budgeting system: influences on managerial behavior and performance. The Accounting Review, v. 56, n. 4, p. 813-829, 1981. Available at: <http://www.jstor. org/stable/247203>. Accessed on: Jan. 11, 2018.

MEYER, J. P.; HERSCOVITCH, L. Commitment in the workplace: toward a general model. Human Resource Management Review, v. 11, n. 3, p. 299-326, 2001.

MICHAUX, V. Articular as competências individual, coletiva, organizacional e estratégica: esclarecendo a teoria dos recursos e do capital social. In: RETOUR, D. et al. (Org.). Competências coletivas: no limiar da estratégia. Porto Alegre: Bookman, 2011. p. 1-21. 
NASCIMENTO, C. A. X.; RUAS, R. L; SILVA, D. Rotinas Organizacionais no Ambiente da Teoria Evolucionária. Revista Ibero-Americana de Estratégia - RIAE, v. 16, n. 3, July/Sept., 2017.

NELSON, R. R.; WINTER, S. G. Uma Teoria Evolucionária da Mudança Econômica. Campinas: Unicamp, 2005. (Translated from the original -1982).

ODELIUS, C. C. et al. Processos de aprendizagem, competências aprendidas, funcionamento, compartilhamento e armazenagem de conhecimentos em grupos de pesquisa. Cadernos EBAPE.BR, Rio de Janeiro, v. 9, n. 1, p. 199-220, 2011.

PARMIGIANI, A.; HOWARD-GRENVILLE, J. Routines revisited exploring the capabilities and practice perspectives. The Academy of Management Annals, v. 5, n. 1, p. 413-453, 2011.

PENTLAND, B. T.; FELDMAN, M. S. Organizational routines as a unit of analysis. Industrial and corporate change, v. 14, n. 5, p. 793-815, 2005

RETOUR, D.; KROHMER, C. A competência coletiva: uma relaçãochave na gestão das competências. In: RETOUR, D. et al. (Org.).
Competências coletivas: no limiar da estratégia. Porto Alegre: Bookman, 2011. p. 45-78.

RUAS, R. et al. Competências coletivas: resultados teórico-práticos acerca de sua configuração em empresas brasileiras. In: ENCONTRO DA ASSOCIAÇÃO NACIONAL DE PÓS-GRADUAÇÃO E PESQUISA EM ADMINISTRAÇÃO, 32., 2013, Rio de Janeiro. Anais... Rio de Janeiro: EnANPAD, 2013.

SANDBERG, J. Understanding human competence at work: an interpretative approach. Academy of Management Journal, v. 43, n. 1, p. $9-25,2000$.

SILVA, F. M. O que sabemos sobre competências coletivas? In: ENCONTRO DA ASSOCIAÇÃO NACIONAL DE PÓS-GRADUAÇÃO E PESQUISA EM ADMINISTRAÇÃO, 36., 2012, Rio de Janeiro. Anais... Rio de Janeiro: EnANPAD, 2012.

SILVA, F. M.; RUAS, R. L. Competências Coletivas: Considerações acerca de sua formação e desenvolvimento. REAd. Revista Eletrônica de Administração, Porto Alegre, v. 22, n. 1, p. 252-278, 2016.

Samantha Luiza de Souza Broman

ORCID: https://orcid.org/0000-0001-5239-8629

Masters in Corporate Management from the Pontifícia Universidade Católica in Rio de Janeiro (IAG/PUC- Rio) and currently studying for a Doctorate at the same university. Professor at the Universidade Federal do Rio de Janeiro (UFRJ), Rio de Janeiro - RJ, Brazil. E-mail: sambroman@ hotmail.com

Roberto Lima Ruas

ORCID: https://orcid.org/0000-0002-2901-6378

Doctorate in Economics from the Université Jules Verne, France. Masters in Economics from the Université Paris I - Sorbonne, France. Professor on the Postgraduate Program in Management at the Universidade Nove de Julho (UNINOVE), São Paulo - SP, Brazil. E-mail: roberuas@gmail.com

Sandra Regina da Rocha-Pinto

ORCID: https://orcid.org/0000-0002-5121-4231

Doctorate in Education and Masters in Corporate Management from the Pontifícia Universidade Católica in Rio de Janeiro (IAG/PUC- Rio). Professor at the Corporate Management Department (IAG/PUC-Rio), Rio de Janeiro - RJ, Brazil. E-mail: sanpin@iag.puc-rio.br 